\title{
AMTEX First Quarter FY95 Report
}

\section{The AMTEX Partnership ${ }^{\mathrm{m}}$}

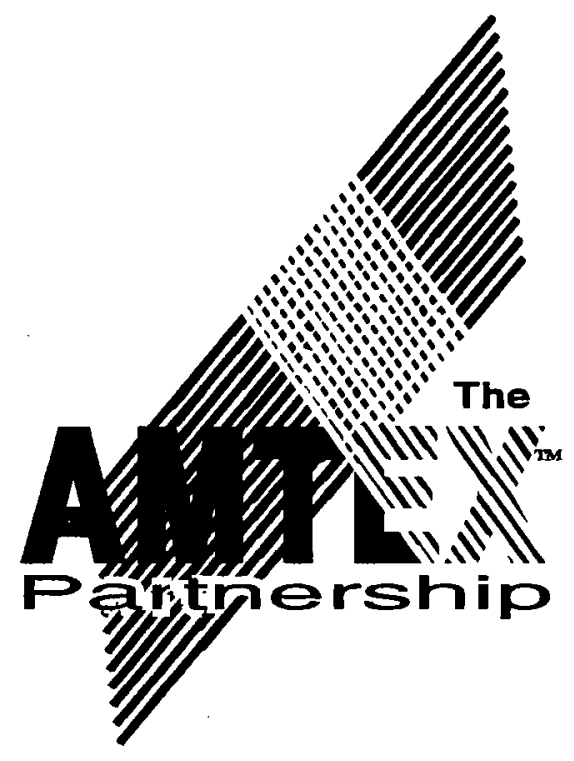

December 1994 


\title{
DISCLAIMER
}

This report was prepared as an account of work sponsored by an agency of the United States Government. Neither the United States Government nor any agency thereof, nor Battelle Memorial Institute, nor any of their employees, makes any warranty, expressed or implied, or assumes any legal liability or responsibility for the accuracy, completeness, or usefulness of any information, apparatus, product, or process disclosed, or represents that its use would not infringe privately owned rights. Reference herein to any specific commercial product, process, or service by trade name, trademark, manufacturer, or otherwise does not necessarily constitute or imply its endorsement, recommendation, or favoring by the United States Government or any agency thereof, or Battelle Memorial Institute. The views and opinions of authors expressed herein do not necessarily state or reflect those of the United States Government or any agency thereof.

\author{
PACIFIC NORTHWEST LABORATORY \\ operated by \\ BATTELLE MEMORIAL INSTITUTE \\ for the \\ UNITED STATES DEPARTMENT OF ENERGY \\ under Contract DE-ACO6-76RLO 1830
}




\title{
The AMTEX Partnership \\ First Quarter Report Fiscal Year 1995
}

\author{
December 1994
}

Issued by

The AMTEX Program Office

Douglas K. Lemon, Manager

AMTEX Laboratory Program Office

and

Richard K. Quisenberry, Executive Director

AMTEX Industry Program Office 


\section{CONTENTS}

Executive Sum mary ......................................................................

Operations and Program Management........................................... $\quad 7$

Program Office Operations and Management......................... 7

Operating Committee Activities and Actions for the Quarter.

Project Accomplishments ............................................................ 10

Computer-Aided Fabric Evaluation ........................................... 10

Cotton Biotechnology ............................................................... 13

Demand Activated Manufacturing Architecture .................. 15

Electronic Embedded Fingerprints........................................... 20

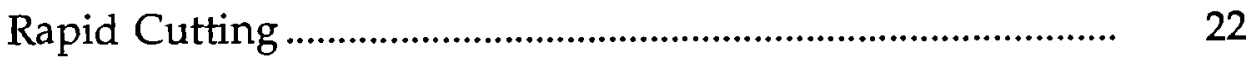

Sensors for Agile Manufacturing.............................................. 25

Textile Resource Conservation ................................................ 26

Financial Summary ............................................................... 28

Appendix A 



\section{EXECUTIVE SUMMARY}

The AMTEX Partnership ${ }^{\mathrm{TM}}$ is a collaborative research and development program among the U.S. Integrated Textile Industry, the Department of Energy (DOE), the national laboratories, other federal agencies and laboratories, and universities. The goal of AMTEX is to strengthen the competitiveness of this vital industry, thereby preserving and creating U.S. jobs.

\section{Operations and Program Management}

The operational and program management of the AMTEX Partnership is provided by the Program Office. This report is produced by the Program Office on a quarterly basis and provides information on the progress, operations, and project management of the partnership.

\section{Program Office Operations and Management}

The AMTEX Operating Committee (AOC) met in November in Wilmington, Delaware, hosted by the DuPont Company. A tour of the nylon fiber plant at Seaford, Delaware, was held the day prior to the meeting. The majority of the meeting time was devoted to progress reports on the on-going projects. A report was also heard from the ad hoc, independent committee that had recently completed a review of the DAMA project. Action was taken on the review committee recommendations regarding management structure. The AOC approved the appointment of Jim Lovejoy as the DAMA Project Director with a person from the laboratories to serve as the Technical Project Manager. Through subsequent nomination and review processes, Leon Chapman of Sandia National Laboratories (SNL) was named the Technical Project Manager.

\section{Project Initiation}

Work on two projects was initiated thisi quater.

- The Cotton Biotechnology project was starrted this quarter with work being done by the Brookhaven National Laboratory (BNL), Lawrence Berkeley Laboratory (LBL), and Cotton Incorporated.

- Progress was made in defining the scope of work and project team for the second new project, On-Line Process Control for Flexible Fiber Manufacturing or OPCon Project. The industry research partners identified and prioritized several areas of R\&D needs. Proposals were submitted by the laboratories. 
Projects

\section{Computer-Aided Fabric Evaluation (CAFE)}

Over the past quarter, the CAFE Laboratory Team has made significant progress toward all milestones and deliverables. For the On-Loom Greige Inspection Task, progress has been made in the areas of sensor development, real-time signal processing, and algorithm development, as they apply to the Alpha Test Configuration. In particular, the On-Loom Greige Laboratory Team has completed and tested the preliminary design of all the sensor suites that will be deployed during the Alpha Test. In the area of algorithm development, the team extended performance evaluation of all detection algorithms to include feature vector definition and performance assessment, as it applies to real-time defect detection under operational constraints. During this period, the team also investigated issues associated with signal processing and the development and deployment issues associated with the real-time system. These efforts culminated in the current On-Loom Architecture design.

For the Color Printed Pattern Goods (CPPG) Task, the team achieved a major technical milestone with the deployment of the RGB Color Test System. This system included an RGB camera configuration, preliminary graphical user interface, real-time acquisition software, and a web synchronization subsystem. The system underwent final debugging in November with initial deployment at an industry site in December. In other related hardware development, the team developed and tested a new camera interface board which allows multiple labs to use the same color linescan camera in multiple testbed configurations. This quarter also saw significant progress for the CPPG in the area of color pattern defect detection algorithm development.

In other project areas, the team participated in the AOC meeting held in Wilmington, Delaware, and hosted a technology review for the presidents and CEOs of participating Industry Partners. The purpose of this latter meeting was to review and provide technology demonstrations of the sensors being deployed in the select inspection systems. In addition, an overview and presentation of the project was given to DOE Headquarters as a review to show programmatic structure and approach for taking technology to commercialization.

\section{Cotton Biotechnology}

A project meeting and two meetings of potential research partners were held. All personnel are in place at BNL. Initial experiments have been carried out in the Fiber Development and Molecular Markers tasks. Two subcontracts are not yet finalized. 


\section{Demand Activated Manufacturing Architecture (DAMA)}

\section{Clarification of the DAMA Project Vision and Goals}

The DAMA project vision is as follows:

By the end of the decade, the Demand Activated Manufacturing Architecture project will link the U.S. Integrated Textile Complex, enabling effective and responsive decisions resulting in a net gain in the global marketplace.

Key to this vision is the enhancement of the small and medium enterprises as a major factor in regaining competitiveness. To realize this vision, the long-range plan of the DAMA project encompasses three goals:

Goal 1: Determine possible strategic business structure changes.

Goal 2: Establish an electronic marketplace for the textile industry.

Goal 3: Engage the entire textile industry in DAMA activities.

The 1995-1996 DAMA project plan, which was written during this quarter, specifies eight objectives that, when met, will enable the DAMA project to achieve the three goals just listed. In addition to restating the linkage between each task and its underlying goal and objectives, the plan details 1) the approach to be taken to achieve the task objectives, 2) the specific strategies planned for carrying out the approach, and 3) the deliverables, schedule, and DOE national laboratory resources required to accomplish each task. This project plan, DAMA-1-G-95, will be published in January, 1995.

\section{Key Highlights}

- DAMA completed a peer review by an External Review Committee (ERC). In general, the ERC provided high marks for the amount of progress that had been made in the last few months of the project which included the new technical project structure and the plans for 1995-1996 efforts. Jim Lovejoy, Textile/Clothing Technology Corporation $[\mathrm{TC}]^{2}$, is the new DAMA Project Director and Leon Chapman, SNL, has been assigned as DAMA Technical Project Manager.

- Clarification and agreement on the FY95 funding with DOE has been obtained.

- A baseline industry model for men's cotton wrinkle-free slacks product line has been completed. It is available in an electronic format on Internet using a Mosaic Browser. The model accounts for process times, transportation times, and records the major information flows within the product line. 
- The Cooperative Business Management (CBM) Prototype I final design review was completed in November. Development and preparation for a late January evaluation by the U.S. Integrated Textile Complex (ITC) of the CBM Prototype has been on-going. The prototype will demonstrate the sharing of information from retail to manufacturing to the mills. Data includes forecasting, point-of-sale information, inventories, and displays of that information while using the Internet as the national information highway.

\section{Embedded Electronic Fingerprinting (EEF)}

The EEF project is developing miniature electronic devices as permanent identification markers and information stations for textiles and apparel. Although this is a dual laboratory effort, Pacific Northwest Laboratory (PNL) ${ }^{1}$ received funding in May and Lawrence Livermore National Laboratory (LLNL) was funded in November. Initial efforts have been devoted to identifying the state-of-the-art technologies in the rapidly changing radio frequency identification device (RFID) area. An exposition of the most advanced capabilities will be held at $[\mathrm{TC}]^{2}$. The leading candidate technologies will be matched with the industrial needs list. It is not yet clear that an exact match will emerge; if not, the $R \& D$ will focus on the advancements necessary (either in the commercial or national laboratory sectors) to produce a useful product.

\section{Rapid Cutting}

The Rapid Cutting project consists of a team of 6 national laboratories and 15 Industry partners. The Laboratories have technologies appropriate for the single layer, single garment cutting of textiles to attain a quick response manufacturing capability at breakthrough cost/performance levels. This goal will be achieved through deployment of mechanical cutting systems, improvements in blades, and by the development of next generation research laser cutting systems. As of this reporting period, all of the Laboratory teams have commenced work on proof-of-principle demonstration and "quick hit" technology transfer tasks. Advanced materials and coatings have been applied to blades that may substantially improve cutting edge life for current multilayer hand-held and automatic garment cutting systems. Trial cuts on apparel textiles have also been made using different laser sources. Preprototypes of magnetic drivers for automated knife-based reciprocating cutting heads, as well as hand-held cutters, have been made. Optimum ablation or bond breaking requirements using two key laser wavelengths have also been investigated.

1 Pacific Northwest Laboratory is operated for the U.S. Department of Energy by Battelle Memorial Institute under Contract DE-AC06-76RLO 1830. 


\section{Sensors for Agile Manufacturing (SFAM)}

The objective of this project is to develop sensors and feedback control methods that will improve the quality and productivity of the textile industry in the cutting and sewing processes associated with garment assembly. The first tasks in this project are concentrating on the development of sensors for fabric edge detection and felled seam sensing.

Sensor work has progressed substantially during the first quarter of FY95. At PNL, experiments were completed on sensing felled seams optically and electromagnetically. Although neither of these techniques proved feasible for felled seam sensing, very interesting phenomena were observed that may make these sensors useful in other apparel manufacturing applications.

Several Levi Strauss plants in El Paso were toured by the industry project manager, Jim Caldwell, and the laboratory project manager, Kevin Widener. Several different manual felled seaming operations were observed and photographically documented. The project team began in December at Sandia where evaluation of a felled seam sensor, using the same technology, is expected $n$ January.

On the administrative side, a revised Project Plan was submitted that will extend the CRADA period to the end of fiscal year 1997. The current CRADA expires January 16, 1995. On November 8, 1994, a project review was held at DOE Headquarters, followed on November 9 and 10 by a project review at the $A O C$ meeting.

\section{Textile Resource Conservation (TReC)}

This quarter, the industry task teams met to review the information presented by the national laboratory researchers at the project meeting in August. Recommendations from the industry task teams were used to better define the program for the remainder of FY95 and to concentrate on those efforts offering the highest payback in terms of competitiveness for the U.S. textile industry. A workshop on Life Cycle Analysis (LCA) was held in November and delineated the areas where LCA could be used to strengthen the industry's Environmental Decision Tools. Some delays in milestones and some variances in the project plan have been encountered during this quarter due to some minor directional changes in task efforts based on site visits, and subsequent suggestions, by the Industry Partners.

Continued progress has been made in the recovery and reuse of colorant chemicals, and fibrous solid waste. Progress was also made in reducing the amounts of water, chemicals, and energy used in applying chemicals to fabrics and in the cleaning of textile processes complex parts, equipment, and fabrics. Work in the coming quarter will include joint Laboratory/Industry task team meetings, continued refinement of processes, and the development of plans for in-plant demonstrations of technologies. 
Financial Summary (DOE $\$$ in thousands)

\begin{tabular}{lrrrrr} 
& $\begin{array}{r}\text { Total FY95 } \\
\text { Budget* }\end{array}$ & $\begin{array}{r}(\text { B }) \\
\text { Quarter } \\
\text { Cost }\end{array}$ & $\begin{array}{r}\text { FY95 Cost } \\
\text { to Date }\end{array}$ & $\begin{array}{r}\text { Remaining } \\
\text { Balance } \\
(\mathrm{A}-\mathrm{C})\end{array}$ & $\begin{array}{r}\text { (E) } \\
\text { of Budget } \\
\text { (C/A) }\end{array}$ \\
\hline & & & & & \\
\hline Program Office & 1036 & 298 & 298 & 738 & $29 \%$ \\
DAMA & 13,843 & 1,850 & 1,850 & 11,993 & $13 \%$ \\
CAFE & 5,843 & 1,163 & 1,163 & 4,680 & $20 \%$ \\
TReC & 4,292 & 609 & 609 & 3,683 & $14 \%$ \\
EEF & 777 & 117 & 117 & 660 & $15 \%$ \\
Cutting & 2,041 & 268 & 268 & 1,773 & $13 \%$ \\
Sensors & 900 & 127 & 127 & 773 & $14 \%$ \\
Cotton Biotech & 1700 & 48 & 48 & 1,652 & $3 \%$ \\
OPCon & 500 & 0 & 0 & 500 & $0 \%$ \\
TA Leaders & 46 & 7 & 7 & 39 & $15 \%$ \\
Uncommitted & 266 & 0 & 0 & 266 & $0 \%$ \\
& & & & & \\
Total & $\$ 31,244$ & $\$ 4,487$ & $\$ 4,487$ & $\$ 26,757$ & $14 \%$
\end{tabular}

* Total FY95 Budget includes carryover from FY94. (See Project Summary Reports in Appendix A for details.) 


\section{OPERATIONS AND PROGRAM MANAGEMENT}

The AOC provides operational oversight, approves the long-range strategic plan, including project priorities and budgets, and selects the program office and project leaders for the partnership. The AOC consists of representatives from the textile industry, government, and the laboratories.

\section{Program Office Operations and Management}

The Program Office provides management oversight of the daily operational and project activities of the AMTEX Partnership and is composed of an industry and a laboratory component. The following activities were conducted this quarter.

\section{Project Initiation}

- The Cotton Biotechnology project was initiated this quarter with work being done by the Brookhaven National Laboratory, Lawrence Berkeley Laboratory, and Cotton Incorporated.

- Progress was made in defining the scope of work and project team for On-Line Process Control for Flexible Fiber Manufacturing or OPCon Project. The industry research partners first identified and prioritized several areas of R\&D needs. Proposals were submitted by the laboratories addressing these areas. The proposals will be evaluated in the coming quarter and laboratory task leaders selected. Based on nominations from the laboratory members of the AOC, Marc Simpson from the ORNL was selected as the Laboratory Project Manager.

\section{Operating Committee Activities and Actions for the Quarter}

The AOC met on November 10, 1994 in Wilmington Delaware, hosted by the DuPont Company. The major items of discussion and business were:

\section{Welcome and Recognitions}

AMTEX Chair, Jerry Work, welcomed the group to the AOC meeting. Special recognition was given to Nick Hahn of Cotton Incorporated and Tom Malone of Milliken \& Company, both of whom had recently received recognition for their leadership in the industry. Several special guests and first-time attendees were introduced to the group. 


\section{Report of the Executive Director}

Dick Quisenberry, AMTEX Executive Director, summarized the recent accomplishments of AMTEX and highlighted issues surrounding the organization, execution, and resources.

\section{View from the Department of Energy}

David Nelson, Associate Director of Energy Research, gave a viewpoint from the leadership of the Department of Energy. He stressed that DOE is committed to AMTEX, to securing budgets, and to celebrating successes. He related that a new office is being formed called the Office of Information and Technology. Its focus will be on industrial collaborations. Nelson noted that AMTEX has had successes in its brief operation and that he looked forward to contributing to its future success and progress.

\section{Report of the External Review Panel of the DAMA Project}

George Dacey, Chair of the DAMA External Review Panel, gave a brief summary of the panel's findings and recommendations. The overall tenor of the panel's report was positive although areas for improvement were identified. Summaries of the report are available upon request to the Program Office.

\section{Progress Report from Projects}

The project managers for the AMTEX projects reported on the accomplishments and highlights of their projects to date. (Technical progress summaries are given elsewhere in this report and are not repeated here.)

\section{Risk-Complexity Analysis of Projects}

Doug Lemon, AMTEX Laboratory Project Manager, presented an analysis of the AMTEX projects in terms of their risk and complexity components. The point of the analysis was to examine the AMTEX premise that AMTEX would undertake only those projects where three conditions were met:

1) The risk and the technical complexity are so great that no company or group of companies could undertake them alone.

2) The project draws upon the unique expertise and facilities of the DOE national laboratories.

3) The industry beliefs the project as has a major impact on the competitiveness of the integrated industry. 
The analysis showed the AMTEX premise is upheld in the projects now underway and those new areas planned for the coming year.

\section{FY95 R\&D Budgets}

The FY94 and FY95 budgets were presented. A summary of the level of effort (full-time equivalent scientists or engineers) for both the laboratories and industry was presented for FY94 and a projection for FY95. The proposed project budgets for FY95, as approved and recommended by the Industry Technical Advisory Committee, were also presented for discussion.

\section{Operating Committee-Voting on Action Items}

The AOC moved into the business portion of the meeting and took action on the following items:

1) The charter of the Government Operating Board was ratified.

2) Restructuring of the DAMA project.

Jerry Work and George Dacey described the recommendation of the DAMA external review panel that the dual laboratory/industry project management structure be replaced with a more clearly focused structure with an industry Project Director and a Technical Project Manager from the DOE laboratories.

3) The FY95 budgets were considered. A motion to approve the budgets presented was made, seconded, and passed by unanimous vote.

\section{Media and Press Relations}

The media relations effort for this quarter included news releases, major interviews, and the distribution of media information kits. An AMTEX news release on the Cotton Biotech project was produced and yielded placements. A BNL news release was also coordinated.

A major interview on DAMA was coordinated with Time magazine for their special issue on cyberspace. Technology transfer and dual benefits were the emphases of the New York Times article on AMTEX. Coordination and preparation was completed for the National Public Radio interview on the textile industry, carrying messages of new technology initiatives. New contact lists for Congress, media, industry, and other audiences were developed. Over 500 media information kits were distributed to laboratory and industry partners with positive feedback received 


\section{PROJECT ACCOMPLISHMENTS}

During the last quarter, accomplishments within the AMTEX Partnership have been numerous. A review of those accomplishments for each AMTEX project is contained in the following paragraphs.

\section{Computer-Aided Fabric Evaluation (CAFE)}

The CAFE project is developing inspection systems that will provide U.S. textile manufacturers with a major leap forward in the assurance of high quality, consistent textiles.

Project Managers: Glenn Allgood, ORNL/615-574-5673

Marty Ellis, ITT/803-595-0035

\section{Performance Related to Milestones}

\section{a. On-Loom Greige Inspection System}

- Build of Prototype Inspection Systems, including operating and analytic software

- Implementation of the AMTEX/CAFE file server to act as a repository for fabric images captured by the different sensors

- On-Loom Greige Inspection System's Architecture Design

- Preliminary testing of Sandia's sensor under operational conditions.

b. CPPG

- Deployment of the RGB system for test and evaluation in operating plants

- Fabrication, build, and deployment of enhanced Printed Pattern Inspection System.

c. Critical Path Elements

- Completion of On-Loom Greige Inspection System Functional Description and Requirements Document.

\section{Activities and Technical Accomplishments for the Quarter}

On-Loom Greige Inspection System-Argonne, Oak Ridge, Lawrence Berkeley, and Sandia Laboratories

During this reporting period, the Laboratory On-Loom Greige Inspection Team has made significant progress toward the April 3, 1995, Alpha Test date. In particular, Sandia continued the 
development of their fabric imaging sensor culminating in an On-Loom Test of the sensor in November. Based on this successful test, Sandia completed the design for the Alpha Test configuration and submitted it for fabrication. In addition, Sandia started the design for the mechanical mount that will be used to attach the sensor to the loom. Sandia, along with Argonne and Oak Ridge, continued developing software for the DSP real-time system, determining the necessary configuration to acquire and display data in real-time while providing the necessary links for reporting defect feature vectors. In the area of algorithm development, Sandia completed the performance evaluation of detection algorithms for locating pick-wise defects. Four separate algorithms were evaluated. In all cases, the algorithms were able to achieve a 10:1 defect-to-background ratio.

Oak Ridge continued their investigation of the impact of computer vision techniques on loom-made fabric defects. These efforts were expanded to include a front-lit loom mounted system that is being proposed as part of the deployed vision system for Alpha Test. In the area of algorithm development, Oak Ridge continues to enhance the algorithm that has been pursued over the last six months. This same approach will be applied to the front-lit images, maintaining the team's philosophy of a robust, expandable software architecture. In a new diagnostic development, Oak Ridge has developed a frequency domain algorithm that can be used to detect serious structural defects, such as pick density variations, thin places, and mixed fillings. This analytic technique will become a part of the machine diagnostic subsystem.

Argonne continued the development of their non-vision sensor systems. In this effort they completed the design and build of a new compact detection system that will be used as a base line for Alpha Testing. The new design included mechanical and probe geometry which has led to improvements in resolution and sensitivity. The system was demonstrated on President/CEO Day.

\section{CPPG - Oak Ridge, Lawrence Livermore, and Sandia Laboratories}

During this reporting period, the CPPG team completed the development, test, and deployment of the ORNL-designed RGB field test system that was tested at Spartan Mill's Cherokee Finishing Plant. The initial test included base line measurements of vibration, electromagnetic interference (emi), temperature, and humidity. The test was a complete success, capturing over 738 Mbytes of full-color image data. The imagery was loaded onto the national laboratory AMTEX/CAFE data repository, along with other information about the test and image format. The data has been disseminated to the laboratory teams for use in evaluating algorithms for color printed pattern goods. Sandia has performed an initial analysis on the data, using a linear predictive code. The results are encouraging.

In the area of algorithm development, Sandia and Lawrence Livermore made progress in printed color defect detection. Sandia continued to refine an algorithmic concept for handling both edge-type and areatype defects using information derived from CAD files. This 1-D and 
2-D implementation has been developed in the KHOROS environment in preparation for processing the RGB test data.

Lawrence Livermore continued in the evaluation of their statisticbased algorithm using different color spaces. Performance comparisons were made between RGB, HSI, and YQI with HSI providing the best defect discrimination. Livermore also completed the development and testing of a new camera interface board that will allow them and ORNL to use the same color linescan camera in multiple test-beds.

\section{Issues, Major Problems, and Resolutions}

The only major problem to report is the delay in the delivery of the DIPIX board. The vendor agreed upon a November 30, 1994, delivery and has now delayed it until January 30,1995 . The current workaround is to use a DataCube system for image acquisition and then download images to a separate CPU for image analysis and defect characterization, if the board does not arrive in time for integration into the Alpha Test Hardware Architecture.

\section{Explanation of Variances}

None to report this quarter.

\section{Plans for Next Quarter}

For the On-Line Greige Inspection Team, the major thrust for the next quarter will be preparation, planning, and implementation of the Alpha Test at the Y-12 Loom site, commencing April 3, 1995. The test itself will last for approximately 12 weeks, encompassing individual as well as integrated testing of all the selected sensor suites. In support of this test, the team will procure all necessary hardware for implementing the system architecture, design and fabricate all necessary mounting structures for the loom, continue developing algorithms for feature detection and characterization, and develop a database and human interface for reporting defects.

CPPG Team activities for the next quarter will include continued testing of the RGB system at member industry sites. The data gathered will support the testing and enhancements of proposed color and pattern algorithms. In addition, the CPPG Team will continue in its development of the Functional Description and Requirements Document for the CPPG System. Both the On-Loom Greige and CPPG efforts will require participation of the Critical Path Elements Team.

In terms of the Vendor's Consortium, the Team (Lab and Industry) will meet to determine what criteria will be applied in the selection of vendor affiliates. The goal over the next quarter is to have the On-Loom Greige Vendor Affiliate Team in place at the beginning of the Alpha Test. 


\section{Invention Disclosures}

None.

\section{Publications/Presentations}

\section{November 8-9 - AOC Meeting, Wilmington, Delaware}

Glenn Allgood, Ken Tobin, and Gerry Sleefe attended the AOC meeting. Gerry provided a technical progress report on behalf of the Laboratory Team.

\section{November 29-CAFE President/CEO Day}

On November 29, the CAFE Laboratory Team hosted the Presidents and CEOs of the CAFE Industry Partners. The meeting provided an opportunity for the Lab Team to present a firsthand look and demonstration of technology being applied to fabric inspection. The meeting was highlighted by presentations by Dr. Al Trivelpiece (ORNL Director), Dr. Doug Lemon, and Dr. Richard Quisenberry.

\section{December 2, 1994-DOE Headquarters Presentation}

On December 2, a presentation was made to DOE Headquarters in Washington, D.C. The presentation highlighted the approach the project has taken to move from technology to commercialization and the overall management structure. Included in the presentation were highlights and accomplishments of the team to date.

No publications were made during the reporting period.

\section{Cotton Biotechnology}

This visionary project in cotton biotechnology promises to provide revolutionary advancements in the qualities and performance of cotton fiber. By increasing the rate of progress in gene description tenfold, this project will enable scientists to improve the strength, length, and uniformity of cotton. These improvements will add an array of new product features for consumers and a competitive edge for U.S. companies in the world market.

Project Managers: $\quad$ Ben Burr, BNL, / 516-282-3396

Gay Jividen, Cotton, Inc., / 919-881-9874

\section{Performance Related Milestones}

No milestones for this period. 


\section{Activities and Technical Accomplishments this Quarter}

Two meetings were held with potential research partners. The first was on October 3 at Cotton Incorporated headquarters in Raleigh, and the second was held in conjunction with the American Seed Trade Association meeting in Chicago on December 5. Dick Quisenberry attended both of these meetings as well as Hal Brockmann and Gay Jividen from Cotton Incorporated and Ben Burr, BNL. The meetings were to acquaint potential partners with AMTEX and with the Cotton Biotechnology Project. Each meeting drew about 30 participants. Cotton Incorporated has extensively advertised the potential for industry participation in trade journals.

A project meeting was held at BNL on December 3. Gay Jividen and John McCarthy from LBL, as well as most of the BNL team, attended the meeting. The meeting was useful in establishing mutually agreeable expectations. John McCarthy demonstrated the database options available.

Preparation for the Fiber Development Task was begun. Jack van't Hof, BNL, developed a method to make root tip chromosome spreads. The methods he developed form the basis of a Brookhaven Technical Bulletin that he has prepared.

The molecular markers task got off to a strong start. Sequencing began on simple sequence repeat clones obtained from libraries developed with other funds in FY94. These sequences were obtained on an existing automated DNA sequencer at BNL.

All personnel were in place at BNL by the end of December.

\section{Issues, Problems, and Actions to Resolve Them}

The only two aspects of the project that are not in place at BNL are the subcontracts to prepare primers for the molecular markers and to make and manipulate the cDNA libraries.

\section{Explanation of Variances}

No variances.

\section{Plans for the Next Quarter}

The reduced level of funding and the necessity to obtain results in a timely fashion has had its greatest impact on the molecular markers and CDNA sequencing tasks. Basically, the same group will work on both tasks because much of the technology is common to both. The goal is to develop 200 mapped polymorphic SSR markers by the end of FY95. Provided these markers are reasonably evenly distributed on the genetic map, this total should provide an adequate number of markers for plant breeding. Originally, development of 10 times this number 
was planned, primarily to aid in the development of a physical map. Because the physical map is on hold until the project receives substantially more funding, it doesn't make much sense to develop many more markers at this time.

The original plan for gene sequence discovery was to make libraries from different parts of the plant including the development of fiber. It was thought that in developing this database, fiber-specific sequences would become evident by their absence from other tissues. An approach is being taken that will immediately target fiber-specific sequences. Differential amplification will be used to enrich fiber-specific sequences. After sequencing, these clones will be checked for tissue specificity by transcriptional analysis. A conceptual advance was made in identifying the function of fiber-specific sequences that do not have homologues in the sequence databases. Previously plans were to make anti-sense constructs of each of these sequences and transform them back into cotton or into a model plant to see which gene function was interrupted. This process would require a number of transformants for each sequence and would be quite laborious. The new plan is to develop a population of cotton plants that have a high level of transposable element-induced mutations, so that any gene would be interrupted by at least one insertion in the population. The polymerase chain reaction will be used to identify those plants carrying a mutation in a sequenced gene. Examination of the mutant plants should reveal something about the function of the unknown gene sequence. This procedure can conceivably be completed with one transformation of the transposable element construct for all of the genes of interest.

\section{Invention Disclosures}

None.

\section{Publications}

None.

\section{Demand Activated Manufacturing Architecture (DAMA)}

The objective of the DAMA project is to define, develop, integrate, and deliver an electronic marketplace system/structure that can be used by all elements of the U.S. textile industry. DAMA will enable companies to reduce customer complaints and process requests for apparel on demand, and establish new strategic alliances to create business opportunities. These steps will enhance industry productivity and competitiveness in the world marketplace.

Project Director:

Technical Project Manager:
Jim Lovejoy, $[\mathrm{TC}]^{2} / 919-380-2184$

Leon Chapman, SNL / 505-845-8668 


\section{Performance Related to Milestones}

Progress was made toward the four 1994 deliverables as outlined below:

1. Base Line Model document-A base line model of the entire pipeline using a men's cotton wrinkle-free slacks product line was completed and documented during this past quarter. This pipeline study has been presented to the U.S. Integrated Textile Complex (ITC) members of the DAMA project. It was also presented at the last AOC meeting. The business model has been released to the ITC in an electronic format using a Mosaic Browser on Internet. The model for this product line has associated processes, process times, transportation times, and information linkages. The modeling technique has included both an information model and a process model for the men's cotton wrinkle-free slacks product line.

2. Opportunities Assessment Document-The second version of the DAMA opportunities assessment document, previously completed, was used as input for developing the DAMA 1995-1996 plan.

3. Demonstrations-Initial versions of three demonstrations have been completed. These demonstrations are of technology in the areas of 1) electronic procurement, 2) network access to market related information, and 3) an initial simulation of the apparel pipeline. Each of these demonstrations was presented at the 1994 Bobbin Show in Atlanta during September. Several of these demonstrations have been presented at specific DAMA companies at their request. The electronic procurement and Internet access demonstrations have had considerable interest from the U.S. ITC DAMA members. Plans are under way to take these demonstrations to the next Quick Response '95 Conference in Atlanta, Georgia, in March.

4. DAMA Plans-The Draft DAMA 1995-1996 Project Plan was completed and approved by the DAMA Steering Committee. $\mathrm{DOE} /$ Headquarters has also reviewed the plan. Updates to the plan have been completed and detailed DAMA 1995-1996 Task Plans have been submitted. The DAMA project plan and the task plans documents will be published in January, 1995. The DAMA project plan will have a general distribution category (available to anyone having an interest) while the DAMA task plans document will be for internal distribution (DAMA task members).

\section{Activities}

In addition to the activities previously described, related project work has taken place in the following areas:

A major activity during the 1st Quarter of FY95 was the development and construction of the new DAMA technical structure and restructuring 
of tasks. The 1995-1996 DAMA Project Plan has been designed around five major task areas:

1. Enterprise Modeling and Simulation Task

2. Connectivity and Infrastructure Task

3. Cooperative Business Management Task

4. Education and Outreach Task

5. Architecture and Commercialization Task

The whole concept of the DAMA plan is now based on a single vision, supporting goals to achieve the vision, objectives that meet the goals, strategies required to meet the objectives, and the individual task activities to satisfy the strategies. This top down structure permits improvement of the basic project management principles, including milestone tracking, costing of activities, performance, and schedules. With this new DAMA project structure, a more traditional performance of milestones, costing, and tracking has been implemented for the project.

The 1995-1996 DAMA Project Plan (DAMA-1-G-95) has been developed for the 9 months of 1995 and the next 12 months to bring the project planning back to a normal Fiscal Year starting in October. In addition, detailed task plans have been developed and published in the 19951996 DAMA Task Plans document (DAMA-2-I-95). During the development of the 1995-1996 Project Plan and based upon the available funding, the project managers determined the number of laboratory participants (nine) should be reduced. Given the resources available and new work assignments, Argonne National Laboratory and Brookhaven National Laboratory will not be participating in the DAMA project after January 1995. This still leaves seven national laboratories and 32 companies that are participants on the DAMA project.

Clarification of funding for FY95 has been accomplished with agreement by both DOE/DP and DOE/ER at DOE headquarters. The preceding plans were developed with estimated funding levels for FY96. The extension of existing CRADAs is being processed.

An External Review Committee (ERC) conducted a two-day review of the DAMA project in late September, 1994, and published a report in mid-October 1994. In general, the ERC provided high marks for the amount of progress that had been made in the last few months of the project, including the new technical project structure and the plans for 1995-1996 efforts. The committee thought the project was very worthwhile, was of national interest, and the laboratories could definitely play a major role in solving a very difficult problem for the U.S. ITC. In light of the recent improvements in the structure of DAMA, they recommended a revisit in 6-9 months by the ERC as a useful exercise to assure the project was staying on track. The ERC also recommended reductions in the number of laboratory participants for the project. Several areas of improvement were recommended by the review team. 
Based upon the ERC report and comments, Jim Lovejoy, $[\mathrm{TC}]^{2}$, has been appointed the DAMA Project Director. In addition, a new DAMA Technical Project Manager, Leon Chapman, Sandia National Laboratories, has been appointed to the project.

The AMTEX Collaborative Information System (ACIS) has been implemented to ensure that all research partners can easily connect electronically. The DAMA project set a goal to send all correspondence electronically, using e-mail. A DAMA server on Internet has been established at Lawrence Livermore National Laboratory (LLNL) to allow files to be saved and transferred over Internet using the File Transfer Protocol (FTP). This DAMA server is also being used for echoing or distributing an e-mail message to members who are on a group distribution list, such as the DAMA Steering Committee, Task members, and others. An offer has been extended to other DAMA projects that require connectivity and have the resources to provide for it.

A demonstration has been developed dealing with the Auburn sourcing database. It currently includes all textile and apparel manufacturers in the state of Alabama. A National Textile Center (NTC) project is currently expanding the database to include the states of North Carolina, South Carolina, and Georgia. A user friendly graphical interface has been completed for the Auburn sourcing database. This system is currently being set up at $[\mathrm{TC}]^{2}$ for access over the Internet. Plans are to have the database available on the Internet World Wide Web by using a Mosaic type interface.

A final design review by the Cooperative Business Management Task was held at Clemson Apparel Research Center in November, 1994. The participating DAMA members approved the final CBM Prototype I design to be evaluated in late January. The CBM Prototype I will demonstrate the sharing of information, such as forecasting information, inventory, and point-of-sale data through the sectors of retail, manufacturing, and the mills. Multiple companies in each sector have provided historical data for the denim jeans product line. Trading partners up and down the chain will be implemented to ensure data is not available to competitors but only through trading partner agreements. A series of evaluations will be held during the week of January 23 rd at $[\mathrm{TC}]^{2}$ to evaluate the utility of the CBM Prototype I.

The CBM prototype has been constructed by using a client-server architecture with distributed databases. Servers have been established on the Internet at INEL, ORNL, and SNL. Conceptually, the data for the retail sector is at SNL, data for the manufacturing sector resides at INEL, and the mill sector data is maintained at ORNL. The Internet serves as the national information highway for this prototype. Microsoft's products of Windows NT operating system, SQL server, Visual Basic, and Access are the primary components for this Prototype I. If the system is successful in the evaluation step, the prototype could move to a pilot involving live U.S. ITC data and their facilities. 
A DAMA Steering Committee was held in December, 1994, in Greensboro, North Carolina. Each DAMA task presented a summary of their activities during the past year. In addition, a complete description of their proposed work for FY 95 was given. A summary report of activities by each task during the last year was presented to the Steering Committee. An annual report is being prepared covering the first year of DAMA work.

\section{Issues, Major Problems, and Resolutions}

None to report at this time.

\section{Explanation of Variances}

No significant variance to report.

\section{Plans For Next Quarter}

Next quarter, the DAMA team will concentrate on demonstrations for the Quick Response '95 Conference in March, 1995 and the demonstrations for the AOC March meeting in Washington, D.C. with DOE and other officials. The CBM Prototype I evaluation will occur in late January. These events will be valuable in gaining feedback from industry representatives both inside and outside of the DAMA project. Several of the work activities included in the first year CRADA will be completed in the second quarter of FY95. New work will start according to the 1995-1996 DAMA Project Plan during this quarter. The implementation of the national sourcing database will be established at $[\mathrm{TC}]^{2}$ along with an Internet server to begin the showcase of DAMA activities and products at $[T C]^{2}$. Preparation of the DAMA annual report will be completed.

\section{Invention Disclosures}

None.

\section{Publications / Presentations}

Defining a Focus for the Development of Decision Analysis Tools: The Vital Issues Process, DAMA-S-2-94, V1.0, June, 1994 (CRADA Protected). 


\section{Electronic Embedded Fingerprints (EEF)}

The Electronic Embedded Fingerprint project is developing miniature electronic devices as permanent identification and information markers for textiles and apparel.

Project Managers: $\quad$ Mike Riley, LLNL/510-422-3045

Jim Caldwell, [TC] $]^{2} / 919-380-2156$

\section{Performance Related to Milestones}

The first two EEF milestones were completed on schedule during this quarter:

1) The technology assessment to identify leading edge tagging technology companies is complete. About two dozen organizations with the capability of producing hardware have been identified. Although many other companies exist, they are not actual primary producers, but rather repackagers. This area of technology is such a dynamic area that no single document will do more than capture the present status of the industry. Accordingly, EEF intends to continue its survey on a less formal basis and provide updated information on other possible producers each quarter.

2) An industrial statement of need/tag criteria has been completed. This list is a most important step in guiding the research direction.

A Sources Sought announcement has been written for publication in the Commerce Business Daily. The objective is to identify viable commercial RFID companies that may have been overlooked in the technology survey. Jim Caldwell of $[\mathrm{TC}]^{2}$ has agreed to place the announcement. When the responses have been evaluated, candidates from the earlier survey and the CBD candidates will be invited to an RFID Exposition at $[\mathrm{TC}]^{2}$ that will allow a two-way evaluation process to begin: first, the AMTEX partnership will be able to assess whether or not any commercial entities have a suitable product line for their needs or the interest and capabilities to develop product(s) in a timely fashion. Secondly, industry can assess if a suitable market exists to justify necessary development efforts.

\section{Activities and Technical Accomplishments for the Quarter}

A microprocessor has been chosen for use in the prototype read/write tag. It has the following attributes: very low power consumption, small size, and considerable flexibility. Code is being developed to store and receive tag data from the non-volatile memory, communicate with the tag reader, and synchronize delay based upon the tag serial number. 
A test board containing seven prototype units was fabricated in order to provide a test system for software development. In this way, the problems (for example, clashing), involved with multiple tags transmitting at the same time, will be assessed.

Statistical analysis has shown the probability of successfully communicating with many tags within a short time frame is acceptable. Preliminary RF power measurements have shown that, although sufficient power is available, it must be configured differently.

Evaluation of commercially available non-volatile memory options components is underway. It appears that a monolithic version of EEF is technologically possible. Issues of cost can be evaluated when a specification of the complete operation of the tag is available.

Possible system architectures for RF tag powering and communication have been identified. A prototype tag powering circuitry for tag receiver modules was designed, and calculations of output power from it were made. The resulting output power was approximately a factor of 2 less than that required.

Representatives from [TC] $]^{2}$, PNL, and LLNL visited a tag vendor in San Diego to learn about their technical capabilities. The company plans, in about six months, to produce an RFID tag that may be capable of meeting many of the AMTEX needs.

Representatives from the AMTEX Automation projects and $[\mathrm{TC}]^{2}$ toured Haggar facilities in Harlingen, Texas, and Levi Strauss plants in El Paso, Texas.

\section{Issues, Major Problems, and Resolutions}

Two RFID organizations have contacted the EEF project, asking to be included in our list of leading edge manufacturers. Because it is impossible in a field as dynamic and diverse as this one is to stay abreast of all of the developments and companies, the survey list will be updated quarterly.

\section{Explanation of Variances}

No significant variance to report.

\section{Plans for Next Quarter}

Participate in AOC meeting and demonstration at Washington, DC.

Participate in planning RFID Exposition at $\left[\mathrm{TC}^{2}\right.$ and analysis of commercial RFID capabilities.

Tour Wichita Falls, Texas, Levi Strauss Plant, possible alpha test site for EEF tags. 
Identify a more appropriate powering antenna structure to meet expected tag powering requirements.

Continue development of system architecture.

\section{Invention Disclosures}

RF Tag - M. A. Doty, LLNL

\section{Publications/Presentations}

Michael Riley made EEF project overview presentations for Diane Bird and Dick Fredlund of DOE Headquarters on November 8 and for the AOC meeting in Wilmington on November 10.

\section{Rapid Cutting}

The Rapid Cutting project is developing a new generation of cutting systems and technological advancements in current systems that will improve cutting quality and efficiency. Such systems will enable true demand activated manufacturing of apparel. The Rapid Cutting project consists of six national laboratories, each with laser and optical technologies appropriate for the mechanical cutting of textiles using new materials and photonics.

All teams were actively involved with their tasks during this quarter.

Project Managers: $\quad$ Craig Fong, LBL/510-486-5298

Jim Caldwell, [TC] $]^{2} / 919-380-2156$

\section{Performance Related to Milestones}

Phase One consists of proof-of-principle experiments to meet the longer term objectives of 200 inches/second single ply, single garment cutting, and piece part sequencing at a target capital cost of $\$ 50 \mathrm{~K}$. Also included are near-term technology applications for commercial lasers and blade cutting systems. An aggregate start date was August 1, 1994, with the period of performance concluding January 15, 1995, the date for a major technical project review. This review earmarks task specific milestones. Task descriptions and a brief assessment of status follows:

Task 1 - Improved Blades - Provide new post manufacturing and new materials for cutting edges and blade bodies. Progress: Blades from industry received, processed, and manufactured an initial trial lot for the Bobbin Show. Status: On schedule. 
Task 2 - Advanced Cutting Heads - Provide improvements to existing automated commercial cutters. Progress: Alpha typical drivers now being fabricated. Status: On schedule.

Task 3.1 - $\mathrm{CO}_{2}$, YAG:Nd Lasers - Provide improvements to commercial laser sources and optical transport systems. Progress: Fabricated cutting box for lab lasers and conducted first trial cuts on textiles. Status: On schedule.

Task 3.2 - UV Cutting - Develop next generation systems and test new laser sources for textile cutting. Progress: Trial cuts on textiles has commenced. Status: On schedule.

Task 3.3 - Solid State Laser Cutting - Test several next generation laser sources for textile cutting. Progress: The LLNL CRADA is still in the approval process. The final Joint Work Statement/Statement of Work (JWS/SOW) is being reviewed by the local operations office. Status: Two months behind budget and schedule benchmarks. A recovery plan has been formulated.

Task 4 - Material Handling - Develop cost effective single garment piece part sorting and sequencing systems. Progress: System requirements, site evaluations, and a conceptual design effort have started. Control algorithms have also been identified. Status: On schedule.

Task 5 - Task Management - Level of effort management for these tasks. Progress: Almost all of the work is underway. Status: On schedule.

\section{Activities and Technical Accomplishments for the Quarter}

In addition to the accomplishments previously discussed, the following notable events have taken place:

- Industry/Laboratory Meeting - this quarterly meeting was held at $[\mathrm{TC}]^{2}$, Raleigh, North Carolina, to further define tasks, and to identify industry and laboratory teams and needed resources.

- Bobbin Show - examples of cutting blades and a project brochure were prepared and distributed at the annual American Apparel Manufacturers Association (AAMA) Bobbin Show, September 28, 1994, in Atlanta, Georgia.

- Tours of Industry Partners site visits are ongoing. A basic understanding of industry challenges is accumulating. 
Issues, Major Problems, and Resolutions

Task 3.3 (Solid State Laser Cutting) has not yet started. The CRADA JWS/SOW is still in the funding approval process. As mentioned, the work package is being reviewed by the LLNL operations office. Approval and commencement of work is expected within the next quarter. Because of the Task 3.3 budget of $\$ 130 \mathrm{~K}$ for Phase One and the time remaining, the basic task effort rate will be accelerated. With this acceleration, deliverables for Task 3.3 are expected to be on schedule for the lanuary 1995 major milestone and project review. Issues of CRADA processing times are being addressed by the critical institutions.

\section{Explanation of Variances}

Refer to Issues section.

\section{Plans for Next Quarter}

Task 1 - Complete processing and fabrication of blades. Develop the test plan. Identify beta test sites.

Task 2 - Continue the fabrication of alpha typical magnetic drivers and power supplies. Commence evaluation testing.

Task 3.1 - Continue with optimization testing.

Task 3.2 - Continue with characterization test cutting for two key laser wavelengths.

Task 3.3 - Commence the test cutting for other laser wavelengths.

Task 4 - Continue the development of the conceptual design and development plan.

Task 5 - Continue the level of effort and generate the Project Plan for the ensuing phases.

\section{Invention Disclosures}

LANL has applied for a patent for UV cutting. SNL has applied for one on material handling. LBL has submitted an invention disclosure for magnetic drivers.

\section{Publications/Presentations}

No publications were generated during this reporting period. A general overview of the AMTEX Program and the Rapid Cutting project was presented at DOE Headquarters and the AOC in early November. 


\section{Sensors for Agile Manufacturing (SFAM)}

The Sensors for Agile Manufacturing project team is developing sensors that will allow the automation of sewing processes to improve product quality and process productivity in the apparel manufacturing sector of the U.S. textile industry.

Project Managers: $\quad$ Kevin Widener, PNL/509-375-2487

Jim Caldwell, [TC] $]^{2} / 919-380-2156$

\section{Performance Related to Milestones}

No milestones were scheduled for completion during this quarter.

\section{Activities and Technical Accomplishments for the Quarter}

The strategy behind all prototype development on the SFAM project is to quickly perform bench scale evaluations and, if successful, to proceed to prototype development. These early felled seam sensor investigations were completed this quarter at PNL using optical and electromagnetic sensors. These investigations indicate inherent limitations with both these sensor technologies that prevent the improvement of current state-of-the-art for felled seam sensing. The development of these sensor technologies for felled seam sensing has been halted. However, a common benefit of research is that when looking for a solution to an identified problem one often finds the solution to a totally unrelated problem. This is potentially the case with the PNL work. Possible solutions to problems identified in the August ' 94 joint industry/laboratory meeting were related to these techniques.

The Sandia sensors have been sent for fabrication; the fabric edge detector was received and undergoing laboratory evaluation. These sensors look very promising for detecting the edges of numerous types of fabric. The sensors for the felled seam folder were designed and in the process of being fabricated at the end of the quarter. Felled seam folders were received from $[T C]^{2}$ at ANL, SNL, and PNL.

Kevin Widener, PNL, and Jim Caldwell, $[\mathrm{TC}]^{2}$, visited several Levi \& Strauss plants in El Paso, Texas in December, 1994. This visit was a very informative one with manual felled seam sewing observed and photographed for the benefit of other laboratory researchers. They also met with several of Levi's industrial engineers to gain their expert perspectives on the problems associated with both manual felled seaming and the current state-of-the-art in felled seam sensors. Interaction with sewing machine operators and industrial engineers is invaluable in providing the technical insight necessary to develop any type of sensor that will be part of this project. 
Issues, Major Problems, and Resolutions

None to report this quarter.

\section{Explanation of Variances}

None to report this quarter.

\section{Plans for Next Quarter}

Technical work at the laboratories will continue with prototype sensor development.

A joint industry/laboratory project meeting is scheduled for January 25 at SNL. Project reviews, laboratory tours, and discussion of new tasks will be included.

Planning is underway for presentations at the next AOC meeting in Washington, D.C. in March. At this meeting, SFAM staff plans to demonstrate some of the prototype sensors developed on the project.

\section{Textile Resource Conservation (TReC)}

The objective of the TReC project is to define, develop, integrate, and deliver processes, devices, and techniques to be used by all elements of the U.S. textile and soft goods product chain to enhance environmental quality and minimize the production of wastes.

Project Managers: $\quad$ Paul Farber, ANL/708-252-6522

Don Alexander, ITT/803-595-0035

\section{Performance Related to Milestones}

Performance related to milestones has been satisfactory during the present quarter. Detailed analyses for proof of concepts have been completed, as well as some of the preliminary economic analyses for process concepts. The Recovery of Colorants team has achieved their initial milestones in the recovery of dyes and salts from spent dye baths. Alternative Cleaning Technologies team has identified process conditions for the cleaning of spinnerette heads from fiber manufacturing, and the Low Waste Chemical Application Methods team has verified a concept for placing finishing chemicals on fabric with lower water and energy consumption. 


\section{Quarterly Activities and Technical Accomplishments}

A series of industry task team meetings were completed during the month of October. These meetings were designed to get feedback from the industry partners and determine the efforts to be followed in the remainder of FY95. Based upon the industry meetings, the number of individuals within the tasks was reduced from 29 to 19 . This reduction was due to a combination of factors; some concepts did not prove true; some concepts were more advanced than other similar concepts, and some approaches needed to be delayed until other efforts preceding these in a recovery and reuse scenario, would be proven. Based on this reduction, the updated FY1995 Project Plan was prepared and reviewed by the Industry Project Manager, the Program Office, and the DOE Offices of Energy Research and Defense Programs. A major workshop was held in November on Life Cycle Analysis (LCA) (also called Environmental Decision Tools) in Charlotte, North Carolina. This workshop, attended by over 60 people from the textile ind ustry and the national laboratories, reviewed the key aspects of LCA and some case histories. Joint textile industry and laboratory breakout groups delineated the environmental decisions made in the textile industry, the driving forces to make these decisions, and some ways LCA could help in this decision making process.

\section{Issues, Major Problems, and Resolutions}

The only issues raised this quarter concern the basis for establishing in-plant test sites for the resource recovery beta tests, as well as the criteria for bringing equipment or system manufacturers into the TReC Project. Beta test site locations will be agreed upon between the industrial partners, based on combinations of need, site access, and applicability to the technology being tested. The guidelines for incorporating equipment manufacturers into the TReC program, in order to properly commercialize some of the technologies being developed, are under consideration.

\section{Explanation of Variances}

Variances in milestones and deliverables from the Project Plan are minor and have been due to slight modification in the direction of Laboratory efforts. These modifications were based on recommendations and continued contact between the textile industry teams and the principal investigators in order to better align national laboratory research efforts with textile industry needs.

\section{Plans for Next Quarter}

During the next quarter (January-March 1995), Laboratory researchers whose work will continue into FY95 will continue to refine concepts proven out in FY94. The individual national laboratories will use the Project Plan to develop their individual Statements of Work and proceed with the renewal of their CRADAs and Field Work Proposals. Joint industry/ 
national laboratory task team meetings will be held in January and February. These meetings will review progress to date, discuss the inplant testing plans, and provide adjustments necessary to ensure changes are in alignment with textile industry needs. The Laboratory and Industry project managers will prepare to present the accomplishments of the project to date at the AOC meeting scheduled for early March.

\section{Invention Disclosures}

No invention disclosures have been reported during this quarter.

\section{Publications/Presentations}

No publication or presentations were reported this quarter.

\section{FINANCIAL SUMMARY}

Appendix A contains program financial summary information. 
APPENDIX A

AMTEX FINANCIAL SUMMARY 
PROGRAM SUMMARY REPORT

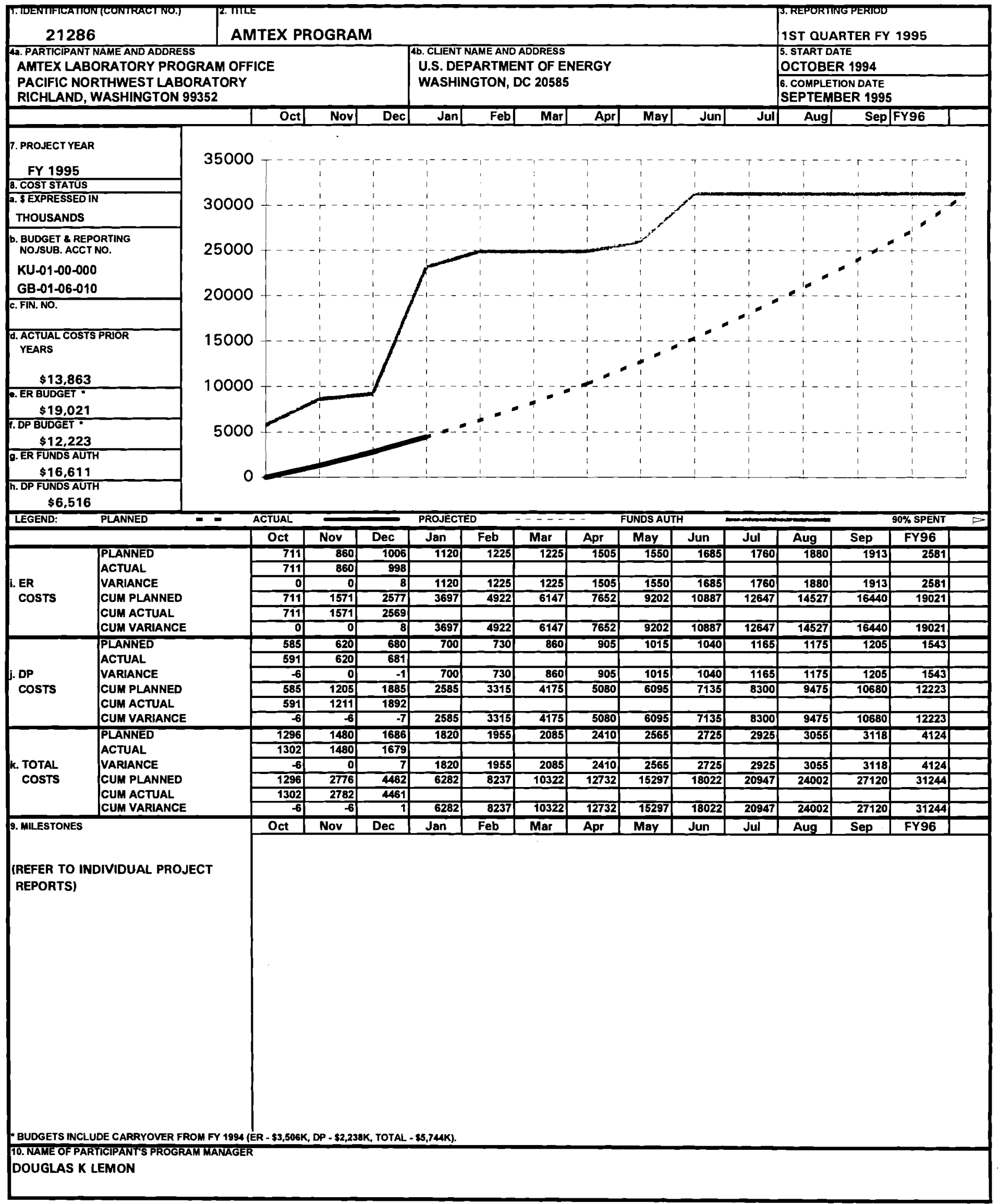


PROJECT SUMMARY REPORT

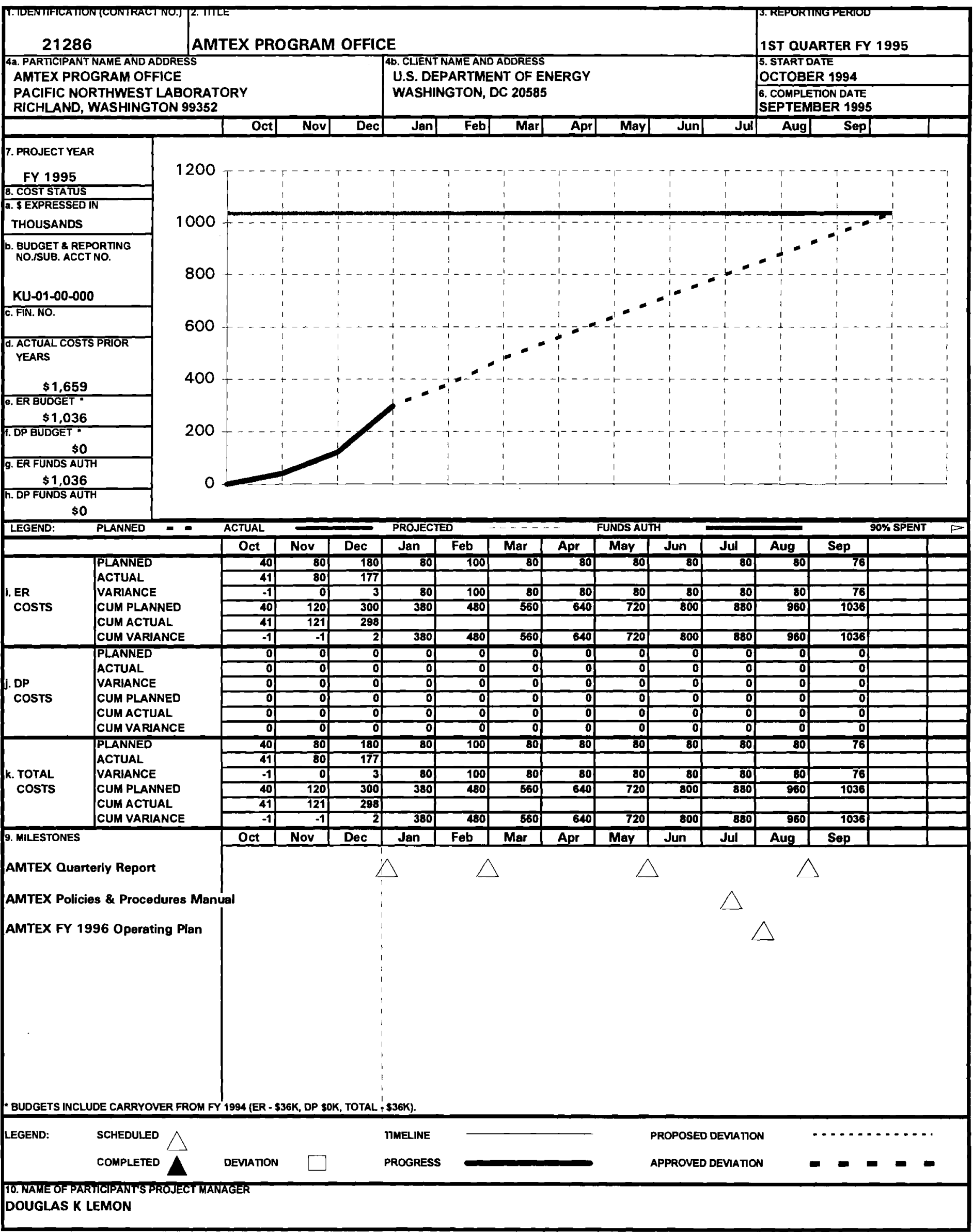


PROJECT SUMMARY REPORT

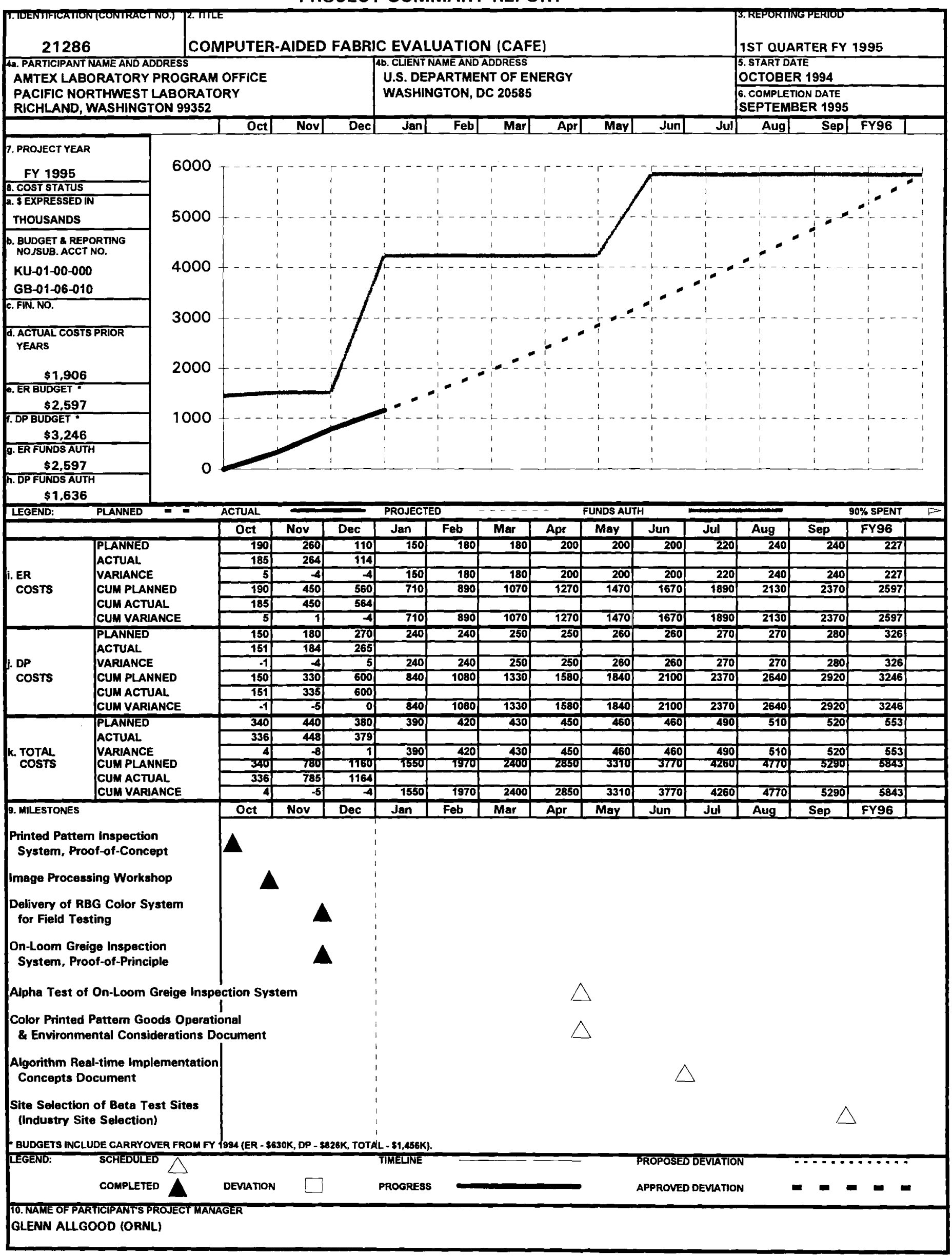


PROJECT SUMMARY REPORT

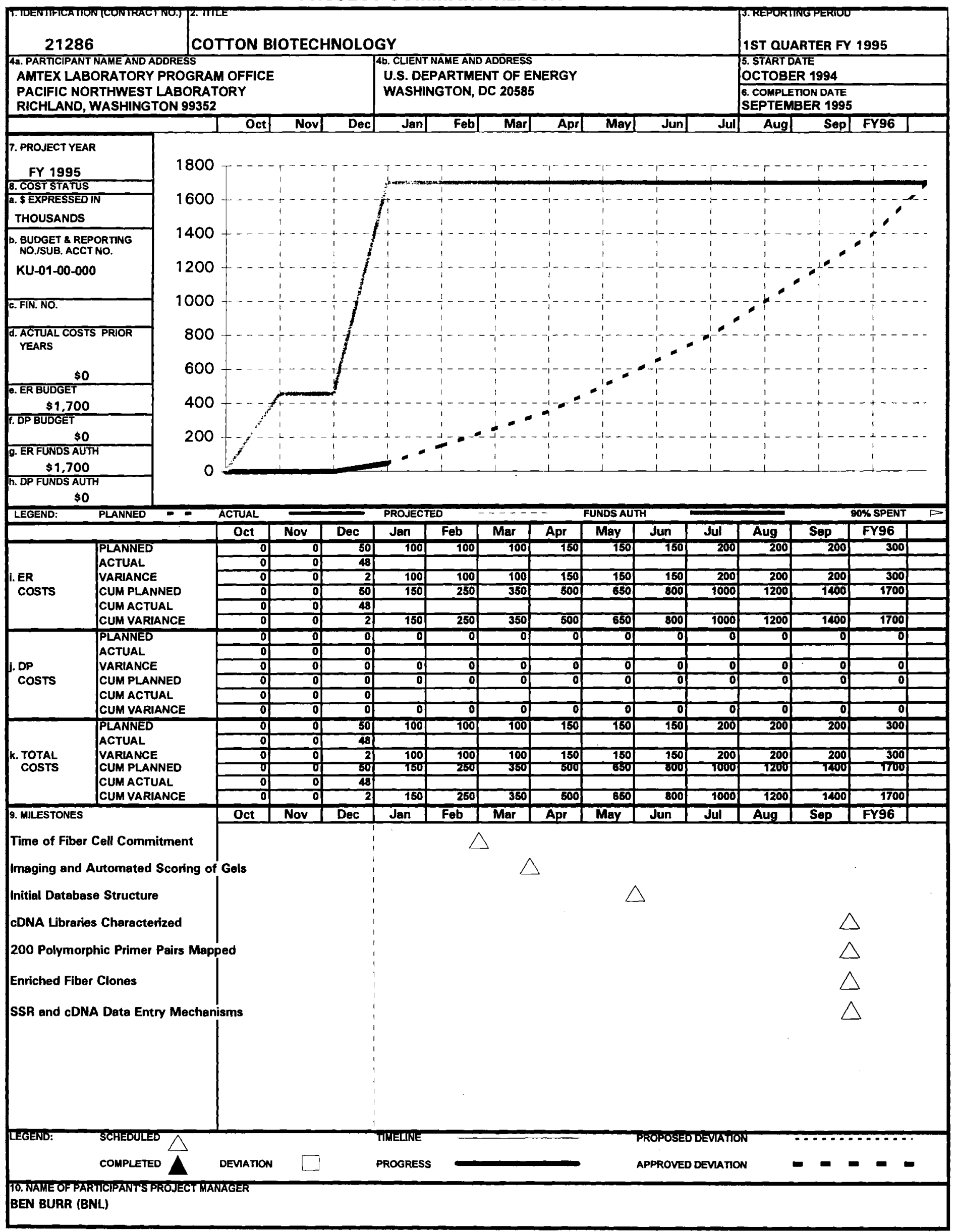




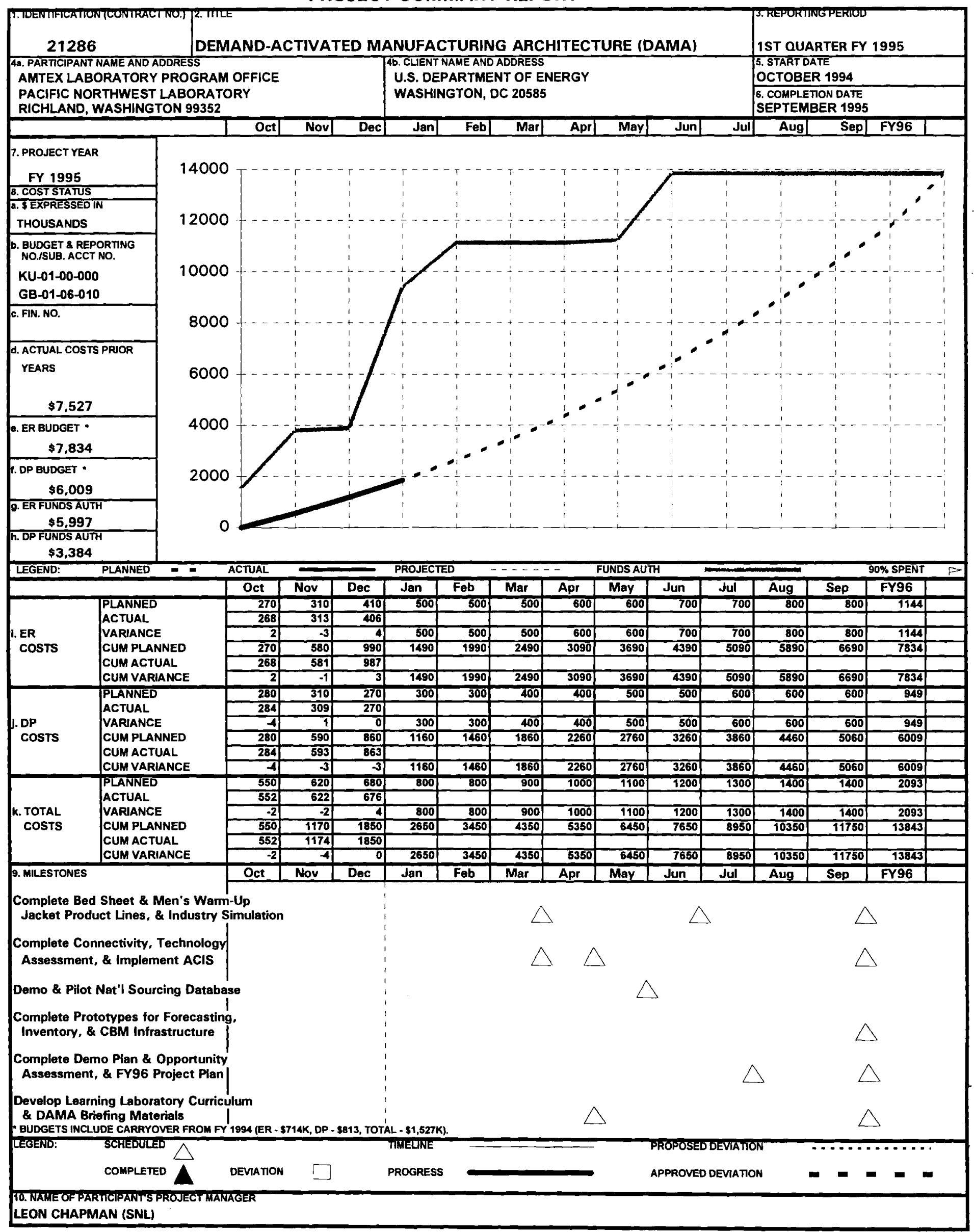


PROJECT SUMMARY REPORT

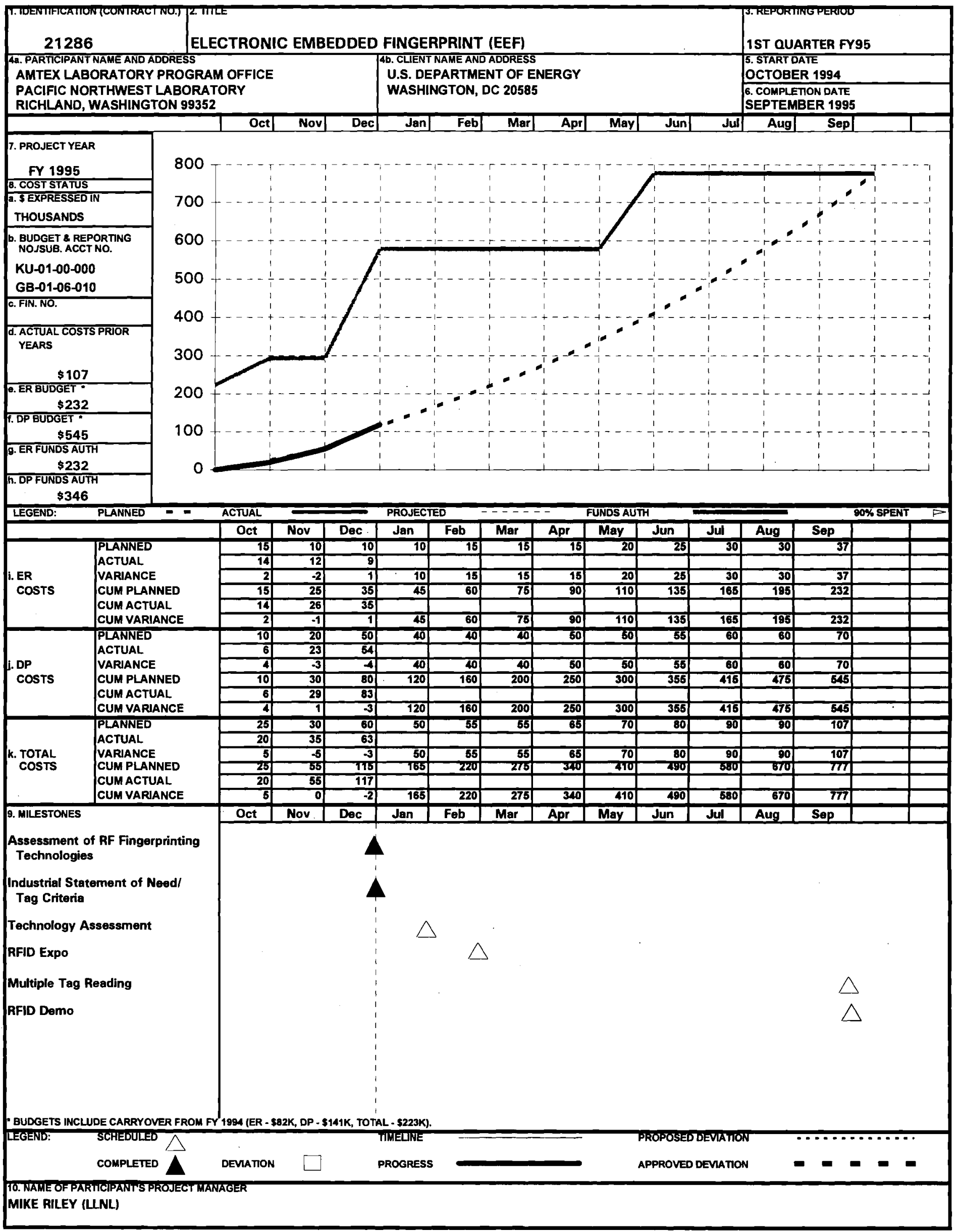


PROJECT SUMMARY REPORT

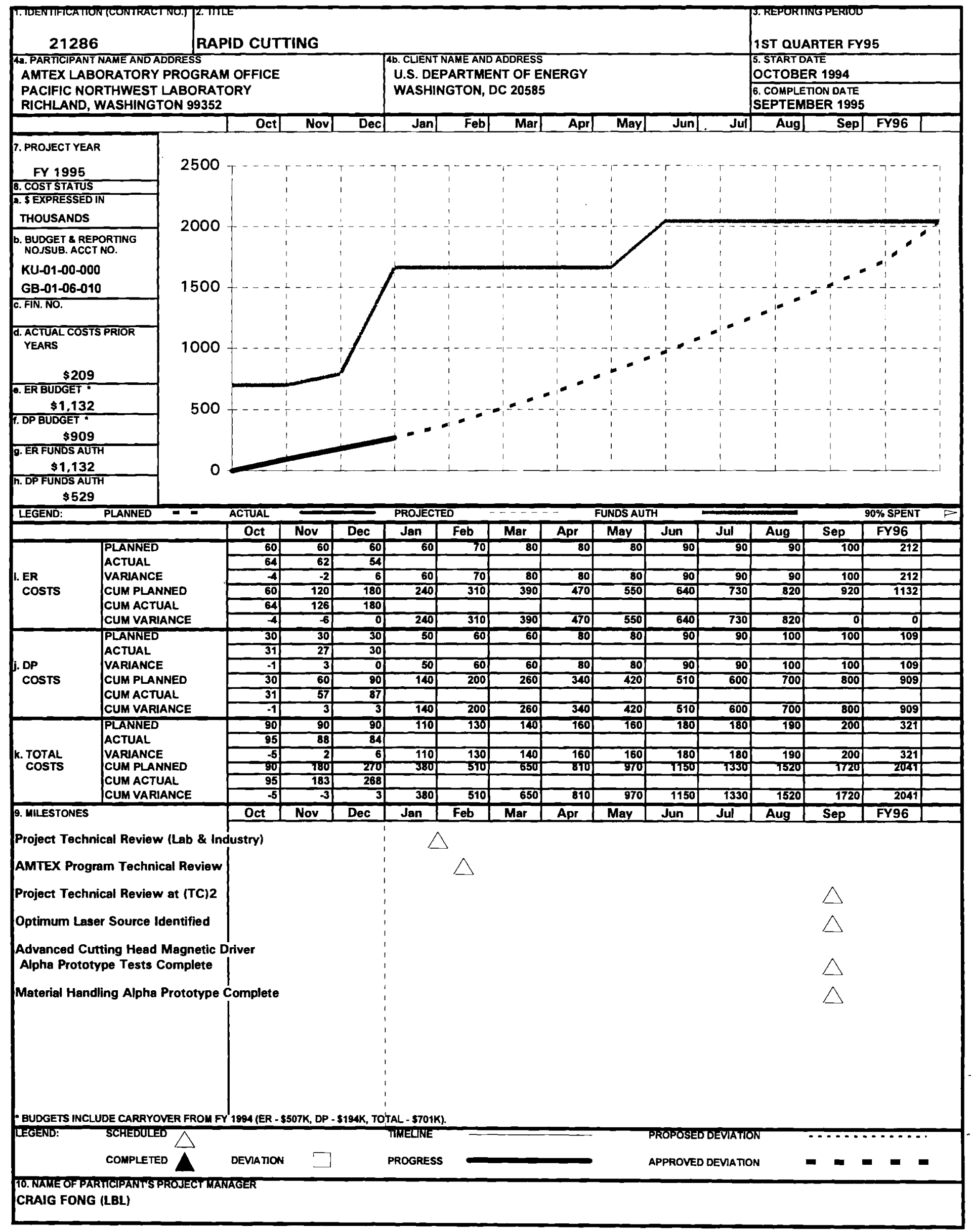


PROJECT SUMMARY REPORT

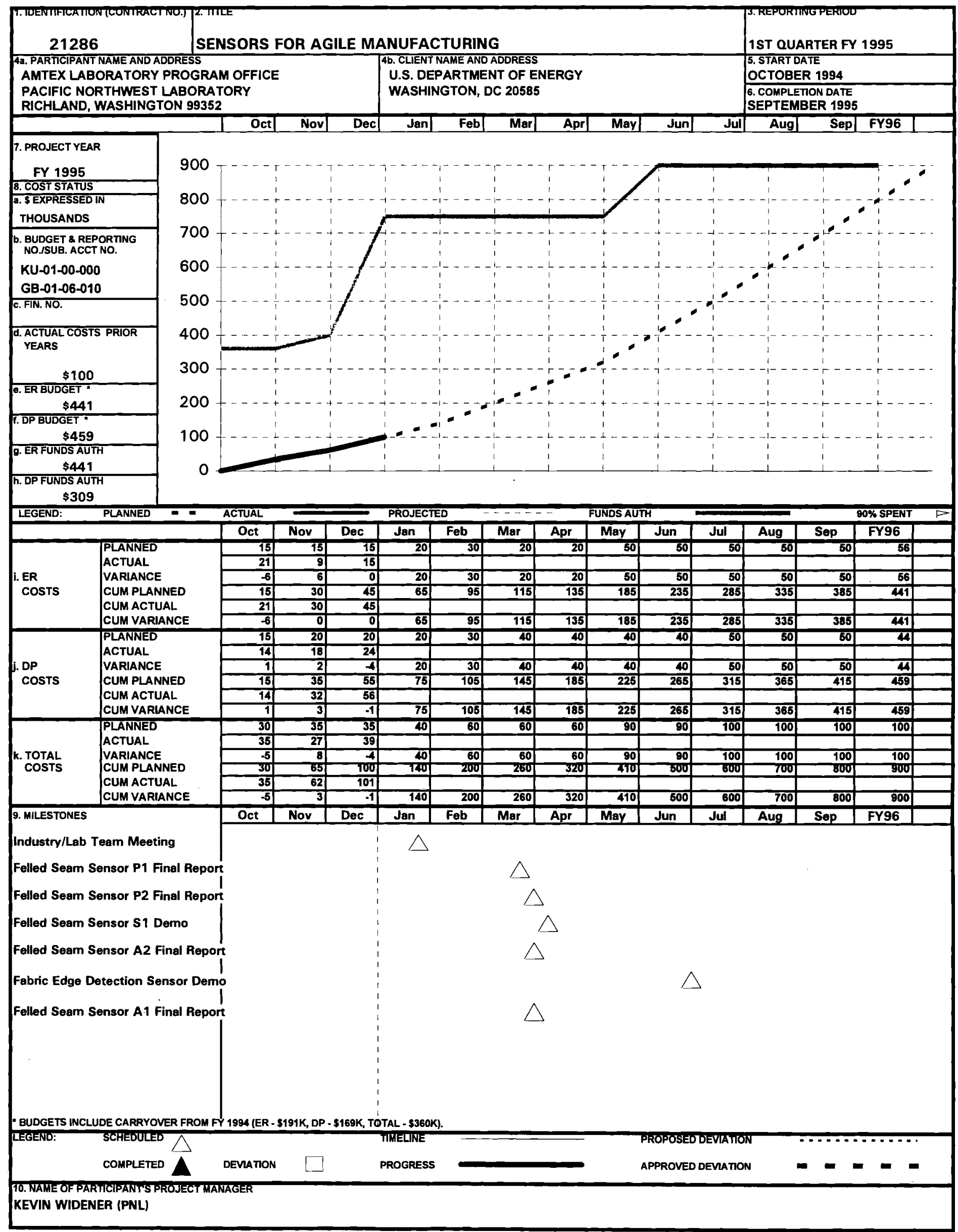


PROJECT SUMMARY REPORT

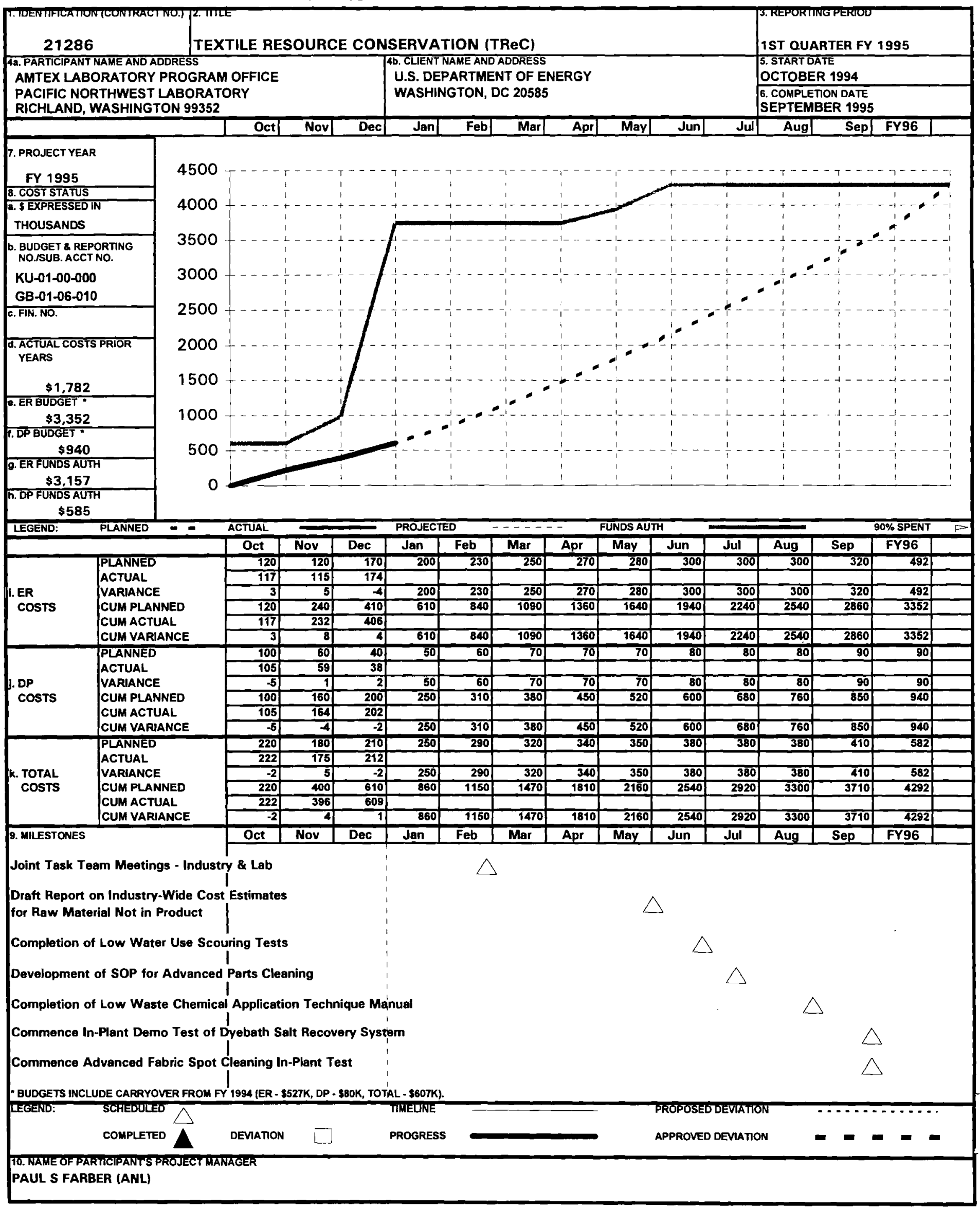




\section{Distribution}

No. of

Copies

Offsite

12

DOE/Office of Scientific and Technical Information

John Adams, President \& CEO

Russell Corporation

Post Office Box 272

Alexander City, AL 35010-0272

Fletcher Adamson, Vice President

Research \& Development

Russell Corporation

P.O. Box 272

Alexander City, AL 35010-0272

Don Alexander, Director Institute of Textile Technology 775 Spartanburg Blvd Suite 104 Spartanburg, SC 29301

Glenn Allgood, CAFE Project Manager (2)

Oak Ridge National Laboratory

P.O. Box 2008

Oak Ridge, TN 37831-6011

Robert A. Barnhardt, Dean

College Of Textiles

North Carolina State University

Box 8301

Raleigh, NC 27693-8301

Prakash Bhatt, Vice President

Business System

VF Corporation

P.O. Box 1022

Reading, PA 19603-1022

Diane Bird

U.S. Dept of Energy, DP-4.1

1000 Independence Avenue

Washington, DC 20585

E.P. Blanchard, Jr.

E. I. Du Pont De Nemours \& Company

P.O. Box 80722

Wilmington, DE 19880-0722

Jerald A. Blumberg, Sr. Vice President

Du Pont Fibers

E I Du Pont De Nemours \& Company

P.O. Box 80722

Wilmington, DE 19880-0722
No. of

Copies

Paul Braxton, Vice President

Textile Products Group

Cone Mills

3101 N. Elm Street

Greensboro, NC 27408

Hal E. Brockmann, Sr. Vice President \& Managing Director

Cotton Incorporated

4505 Creedmoor Road

Raleigh, NC 27612

Sharon Brown, Media Consultant (20)

Battelle Washington Office

901 "D" Street SW / Suite 900

Washington, DC 20024

Edward Burgess, Director Engineering

Lawrence Berkeley Laboratory

One Cyclotron Road/MS:90-1106

Berkeley, CA 94720

Randolph Burnette

Mercantile Stores Company, Inc.

9450 Seward Road

Fairfield, $\mathrm{OH}$ 45014-2230

Peter N. Butenhoff, President (20)

Textile/Clothing Tech Transfer [TC] ${ }^{2}$

211 Gregson Drive

Cary, NC 27511-7909

Ben Burr, Cotton Bio Project Manager (2)

Brookhaven National Laboratory

53 Bell Avenue

Upton, NY 11973

Jim Caldwell, Automation Projects Manager

Textile/Clothing Tech Transfer $[\mathrm{TC}]^{2}$

211 Gregson Drive

Cary, NC 27511-7909

Leon Chapman

DAMA Technical Project Manager

Sandia National Laboratory

P.O. Box 5800 / MS:0722

Albuquerque, NM 87185

Alan Claflin, Director

Laboratory Management Division

U.S. Dept of Energy/LM-10

1000 Independence Avenue

Washington, DC 20585

Distr. 1 


\section{Distribution}

Jerry Cogan Jr., President Milliken Research Corp

P.O. Box 1927

Spartanburg, SC 29304-1927

Harry Collins

Vice President of Research

Delta \& Pine Land Company

One Cotton Row

P.O. Box 157

Scott, MS 83772

Fred L. Cook, Director

School Of Textile \&

Fiber Enginneering

Georgia Institute of

Technology

Atlanta, GA 30332-0295

Joe D. Cunning, Director

National Textile Center

3640A Concord Pike RM 201

Wilmington, DE 19803

George C. Dacey

3171 Laural Ridge Court

Bonita Springs, FL 33923

Pat Danahy, President \& CEO

Cone Mills

1201 Maple Street

Greensboro, NC 27405

James Davenport, Chair

Applied Science Department

Brookhaven National Laboratory

2 Center Street/Bldg 179 A

Upton, NY 11973-5000

Chris A. DeSoiza (5)

Industry AMTEX Liasion

Milliken \& Company

P.O. Box 1926 M-149

Spartanburg, SC 29304

Thomas M. Duff, President

Fibers Division

Wellman, Inc.

1040 Broad Street, Suite 302

Shrewsbury, NJ 07702
Marty Ellis, CAFE Project Manager

ITT Technology Transfer Center

Point West Office Bldg., Suite 104

775 Spartan Blvd.

Spartanburg, SC 29301

Paul Farber, TReC Project Manager (2)

Argonne National Laboratory

9700 South Cass Ave/ES-362

Argonne, IL 60439

Ritchie Fishburne, Director

Corporate Information Systems

Burlington Industries

P.O. Box 21207

Greensboro, NC 27410

James M. Fitzgibbons, CEO

Fieldcrest Cannon, Inc.

One Lake Drive

Kannapolis, NC 28081

Ronald Foltz, Vice President

Technology

Hoechst Celanese Corporation

P.O. Box 32414

Charlotte, NC 28232-9973

Craig Fong, Rapid Cutting Proj. Manager (2)

Lawrence Berkeley Laboratory

1 Cyclotron Road, MS: 90-2148

Berkeley, CA 94720

Jean Ford, Program Manager

CAIS / PDES Testbed

Nat'] Institute of Standards Technology

U.S. Dept. of Commerce

Metrology 220/A127

Gaithersburg, MD 20899

Donald Foster, Technology Leader

Lawrence Berkeley Laboratory

1 Cyclotron Road 90-1106

Berkeley, CA 94720

Dick Fredlund

U.S. Department of Energy/LM-10

1000 Independence Ave

Washington, DC 20585

Allen Gant, President

Glen Raven Mills, Inc.

1831 North Park Ave.

Glen Raven, MO 27217

Distr. 2 
Roger Gilbertson

Program Manager For Basic

Research

U.S. Dept. of Commerce

Mail Code Otexa-H3100

Washington, DC 20230

Rudy Goetzman

Program Development Manager

Westinghouse Savannah River Company

Building 773-42A, Room 135

Aiken, SC 29808

J. Nicholas Hahn

President \& CEO

Cotton Incorporated

1370 Avenue of The Americas

New York, NY 10019

William Harris, President

Textile Fiber Group

Hoechst Celanese Corporation

P.O. Box 32414

Charlotte, NC 28232

June M. Henton, Dean

School of Human Sciences

Auburn University

210 Spidle Hall

Auburn, AL 36849

John F. Hesselberth, Vice President

Fibers \& Reasearch Dept.

E .I .Du Pont De Nemours \& Co.

P.O. Box 80721

Wilmington, DE 19880-0721

Robert H. Jackson

President \& Director

Textile Research Institute

P.O. Box 625

Princeton, NJ 08540

Gay Jividen, Cotton Bio Project Manager

Cotton Incorporated

4505 Creedmoor Road

Raleigh, NC 27612

Chis Kametches

Fieldcrest Cannon, Inc

Sr. V.P. Mfg Engr \& Mfg Svc

One Lake Drive

Kannapolis, NC 28081
Martha Krebs, Director

Office of Energy Research U.S.

Department of Energy

ER-1/7B-058

1000 Independence Avenue

Washington, DC 20585

Glenn W. Larson, Executive Vice President

Mfg. \& Operations

Biltwell Company, Inc.

2005 Walton Road

St Louis, MO 63114

Donald R. Lehman, President

Textile Fibers

Hoechst Celanese Corporation

P.O. Box 32414

Charlotte, NC 28232-9973

H. Vernon Lemaster, President

Dystuffs \& Chemicals Division

Ciba-Geiga Corporation

P.O. Box 18300

Greensboro, NC 27419-8300

Jim Lovejoy, DAMA Project Director Textile/Clothing Tech Transfer $[\mathrm{TC}]^{2}$

211 Gregson Drive

Cary, NC 2711-7909

Roger Malkin, Chairman

Delta And Pine Land Company

One Cotton Row

P.O. Box 157

Scott, MS 387725

Thomas Malone, President \& COO

Milliken \& Company, Inc.

P.O. Box 1926, N-149

Spartanburg, SC 29304

Kathleen McCaughey, Director

SNL AMTEX Programs/Dept. 2700

Sandia National Laboratories

P.O. Box 5800

Albuquerque, NM 87185-0507

Daniel McDonald, Director

Instrumentation \& Control Division

Oak Ridge National Laboratory

P.O. Box 2008/Bethel Valley Road

Bldg. 3500

Oak Ridge, TN 37831-6005 
Dan McCreigth, Vice President Institute of Textile Technology 2551 Ivy Road

Charlottesville, VA 22903-4614

Charles McKeller, Vice President

Glen Raven Mills

1831 North Park Ave.

Glen Raven, NC 27217

Mark Miller (5)

U.S. Departmant of Energy/DP 4.1

1000 Independence Avenue

Washington, DC 20585

Roger Milliken, CEO

Milliken \& Company

P.O. Box 1926, M-149

Spartanburg, SC 29304

David L Nichols, CEO

Mercantile Stores Company, Inc.

9450 Seward Road

Fairfield, $\mathrm{OH}$ 45014-2230

Joseph W. A. Off

Managing Director

Textile/Clothing Tech Transfer [TC]2

211 Gregson Drive

Cary, NC 27511-7909

Lucien Papouchado

Savannah River Technology Center

P.O. Box 616

Aiken, SC 29802

Homi B. Patel, President

Hartmarx Corporation

101 N Wacker Drive 23rd Floor

Chicago, IL 60606

Pete Pesenti, Sr. Research Engineer (10)

U.S. Department Of Energy/LM-10

1000 Independence Avenue

Washington, DC 20585

Norm D. Peterson

Argonne National Laboratory

9700 South Cass Ave.

Argonne, IL 60439

Marty Piltch, Group Leader

Los Alamos National Laboratory

P.O. Box 1663

SM-30 Warehouse

Bikini Atoll Road MS G548

Los Alamos, NM 87545
Larry R. Pugh, Chairman

VF Corporation

P.O. Box 1022

Reading, PA 19603-1022

Richard Quisenberry (20)

AMTEX Industry Program Office

P.O. Box 4670

Wilmington, DE 19807

John Renfro, Vice President

Inman Mills

P.O. Box 207

Inman, SC 29349

Victor Ries, Assistant Secretary

For Defense Programs

U.S. Dept. of Energy / DP-1/4A019

1000 Independence Avenue

Washington, DC 20585

Mike Riley, EEF Project Manager

Lawrence Livermore National

Laboratory

7000 East Ave. L-394

Livermore, CA 94583

Douglas V. Rippy, Director

School Of Textiles

Clemson University

Clemson, SC 29631

Burton B. Ruby

Chairman

Trans-Apparel Group

$5000 \mathrm{~S}$ Ohio Street

Michigan City, IN 46360

Preston E. Sasser, Vice President

Fiber Quality Research

Cotton Incorporated

P.O. Box 30067

Raleigh, NC 27612

Norm Sather, ES/362

Director Energy Systems Division

Argonne National Laboratory

9700 South Cass Avenue

Argonne, IL 60439

Jack Scruggs, OPCon Project Manager (2)

Textile Research Institute (TRI)

129 Coralvine $\mathrm{Ct}$.

Greenville, SC 29116

Distr. 4 


\section{Distribution}

Isiah Sowell

Environmental Management

U.S. Dept. of Energy

1900 Germantown Rd.

Germantown, MD 20585

Robert A. Stokes, Deputy Director

National Renewable Energy Laboratory

1617 Cole Boulevard

Golden, CO 80401-3393

Irving Stowers

Science \& Technology Advisor

Lawrence Livermore National Laboratory

7000 East Ave., MS L-644

P.O. Box 808

Livermore, CA 94550

John Sullivan, Vice President

Business Development

Hoechst Celanese Corp.

P.O. Box 32414

Charlotte, NC 28232

William Toth

Idaho National Engineering Laboratory

P.O. Box 1625

Idaho Falls, ID 83415-2214

Joseph C. Tucker, Director

Reseach \& Development

Wellman, Inc.

P.O. Box 31331

Charlotte, NC 28231

James Van Fleet, Director

Off. of Economic Competitiveness/DP 4.1

U.S. Department of Energy

Defense Programs

1000 Independence Avenue

Washington, DC 20585

Brian Volintine

U.S. Department of Energy

1000 Independence Ave

Washington, DC 20585

George Waldrep, Executive Vice President

Manufacturing

Burlington Industries

P.O. Box 691

Burlington, NC 27216-0691
William K. Walsh, Head

Textile Engineering Department

101 Textile Building

Auburn University

Auburn, AL 36830

Ted Waroblak, President (5)

Institute Of Textile Technology

2551 Ivy Raod

Charlottesville, VA 22903-4614

Frank X. Werber, Nat'l Program Leader

U.S. Department of Agriculture

Bldg. 005/ Room 219 Barc-W

Beltsville, MD 20705

Pete Woody

R\&D Manager

Wellman, Inc.

P.O. Box 31331

Charlotte, NC 28231

Ainsley Young

Los Alamos National Laboratory

Materials Science \& Tech Division

MST-DO, MS A133

P.O. Box 1663

Los Alamos, NM 87545

Anne Marie Zerega

Laboratory Tech Trasfer Program

U.S. Dept of Energy/LM-10

1000 Independence Avenue

Washington, DC 20585

No. of

Copies

$\underline{\text { Onsite }}$

100

Pacific Northwest Laboratory

E. G. Baker

P8-38

D.M. Boyd

K7-02

M.D. Erickson

K7-02

R.W. Gilbert

K5-12

B.J. Harrer

$\mathrm{K} 1-60$

D. K. Lemon (83)

K7-80

W.J. Madia

$\mathrm{K} 1-46$

G.B. Morgan

K7-02

R.E. Rhoads

K8-24

J.A. Roberts

K1-45

K.B. Widener

K5-25

W.R. Wiley

K9-95

G.L. Work

K1-52

Technical Report Files (5) 


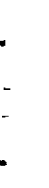

